Use of Surface Analogue for 3-D Geological Modelling of the Arab D Reservoirs - Example from Jabaloyas Outcrops (Eastern Spain)

B.P.R Caline* (Total E\&P France), C. Pabian-Goyheneche (Total E\&P France), J.P. Rolando (Total E\&P France), G. San Miguel (University of Zaragoza Spain), M.

Aurell (University of Zaragoza Spain), B. Badenas (University of Zaragoza, Spain), N. Grasseau (Bordeaux University, France) \& V. Martinez (University of Zaragoza, Spain)

\title{
For abstract, PTO
}

No full paper available 


\section{Use of surface analogue for 3-D geological modelling of the Arab D reservoirs - example from Jabaloyas outcrops (Eastern Spain)}

Galo San Miguel (University of Zaragoza, Spain <galo.sanmiguel@gmail.com>), Bruno Caline (Total), Marc Aurell (University of Zaragoza, Spain), Beatriz Bádenas (University of Zaragoza, Spain), Victor Martínez (University of Zaragoza, Spain), Cecile Pabian-Goyheneche (Total), Nicolas Grasseau (Bordeaux 3 University, France) and Jean-Paul Rolando (Total)

The Arab D Reservoir is one of the most important hydrocarbon reservoirs in the Middle East. Heterogeneity of this reservoir is mainly related to facies distribution and stratigraphic surfaces.

Outcrop analogue is now considered as an efficient tool for better understanding the sedimentary heterogeneity at reservoir scale. This poster illustrates how an Upper Kimmeridgian analogue exposed in northeast Spain has been used to characterise the internal heterogeneities of a low-angle carbonate ramp that includes the development of reef build-ups formed by colonial forms (corals, stromatoporoids), and microbial crusts with associated encrusting organisms. Results from this outcrop analogue have been applied for improving oil recovery from the Arab D Reservoir of a mature field in UAE.

The well-exposed outcrops around the Jabaloyas village (Eastern Spain) have been used for detailed facies and sequence-stratigraphic reconstructions within a 16-22 m thick series. These outcrops show strike and non-strike sections across a $12 \mathrm{sq} \mathrm{km}$ area (i.e. $4 \times 3 \mathrm{~km}$ ). Seventeen stratigraphic profiles were carried out to control vertical and lateral facies distribution. The facies follows an overall retrogradational-progradational trend with the development of low-energy, peloidal-skeletal wackestone-packstone in the middle part of the sequence. Different types of grain-supported facies (ooidal, peloidal, intraclastic, skeletal) are found both in high-energy mid-ramp domains and inner ramp areas. The studied series is bounded by discontinuities that are traceable across a total of $17.5 \mathrm{~km}$ linear distance and encompasses coral-microbial build-ups, 5 to $15 \mathrm{~m}$ high, developed in mid-ramp setting during the stages of maximum accommodation gain. A total of 274 reefs have been mapped across the different reconstructed 2-D transects. Most of them have pinnacle or conical geometry. Wellcemented discontinuity surfaces were used to identify four stages of sedimentary evolution, two of them including individual episode of reef growth. Some trends on the spatial density and on the fabric within each stage have been recorded.

The overall distribution of the main facies was included in a full-field model ( $20 \times 20 \mathrm{~m}$ grid increment) while the geometry, size and distribution of the reefs were better adjusted in sector models $(1 \times 1 \mathrm{~m})$. These models assess the distribution of reservoir bodies and their connectivity. They are now used as a template for diagenesis modelling and constitute the geological input for simulation models. 